\title{
Assessment of Ecotourism in Banaue, Ifugao, Philippines
}

\author{
Milton P. Dulay ${ }^{1}$ \\ ${ }^{1}$ Ifugao State University, Potia, Alfonso Lista, Ifugao \\ ton_iaf@yahoo.com
}

\begin{abstract}
The study utilized descriptive research method to assess the expectation and satisfaction of tourist towards some ecotourism sites of Banaue Ifugao, Philippines. A total of 104 international and domestic/local tourists who visited Banaue ecotourism sites such as Banaue rice terraces, Bangaan rice terraces, Batad rice terraces and Tapiya waterfalls were interviewed using a questionnaire. Frequency, percentage, correlation of variables and analysis of variance were utilized to analyze data. Results show that majority of the tourists are first timers with moderate expectation but much satisfied when personally visited the ecotourism sites. This implies that tourists are not well informed about Banaue ecotourism destinations. Thus, theres a need to strengthen strategic promotional approaches, marketing of the services and programs to tourists, and improve destination attributes to attract tourists.
\end{abstract}

Keywords: ecotourism, expectation, satisfaction, tourist, rice terraces

\section{Introduction}

The municipality of Banaue is known of its endowed natural beauty, refreshing climate and distinctive endowment spells out its ideal role as an ecotourism destination. The diverse attractions of the municipality's natural and manmade ecosystems such as scenic mountains, rivers, rice terraces and rich cultural and historical legacy are spread over the communities which considered being the main hub for ecotourism in the province and as one of the tourist destination in the country.

Over the years, the ecotourism in the municipality of Banaue has been continuously providing livelihood such as inn/hotels, restaurant, tour guide, tricycle/jeep/van for hire, department/sari-sari stores/buy and sell, wood carving, and weaving to the indigenous people and contributes to the economic growth of the province.

Banaue is one of the municipality in Ifugao which belongs to the Luzon cluster of the Tourism Master Plan because of its unique features and the existence of the rice terraces which made it to become a tourist destination. Past national and local initiatives have promoted the natural and manmade tourist potentials in the area through the sustainable management of ecotourism sites and the preservation of the cultural heritage. It commenced with the formulation of the Cordillera Administrative Region (CAR) Tourism Master Plan which gave premium to ecotourism to generate longterm benefits from tourism activities while preserving environmental quality and the region's cultural wealth. Despite the programs tourist arrival continued to miss with actual arrival in the municipality of Banaue and other part of the region. The situation is accounted to poor infrastructure and non-maintenance of tourist attraction areas [1].

The study of the level of expectation and satisfaction according to Singh as cited by A.S. Lather, R. Singh \& K. A. Singh [2a], has paramount significant in so far as sustainable development of tourism at the given destination is concerned. While the level of expectation of the potential tourist acts as a deciding factor in his/her decision to visit a particular destination, the satisfaction level speaks about the quality of the composition of tourist product (attraction + services + socio-cultural status + economic + ecological environment) experienced. Hence, the study was conducted to assess the expectation and satisfaction of tourist visiting some ecotourism sites located at Banaue, Ifugao, Philippines

\section{Ecotourism Sites in Banaue Ifugao}

The main tourist attraction in the province of Ifugao is the Ifugao Rice Terraces (IRT) and it is being promoted by the Department of Tourism of the country as one of the Special Interest Destinations in the Philippines [3]. There are three (3) rice terraces considered in the study that could be found in the municipality of Banaue, two (2) of which are declared by UNESCO as a "Living Cultural Landscape (LCL). The two declared LCL are Batad rice terraces and Bangaan rice terraces. There is also an undeclared LCL known as Banaue rice terraces.

Aside from the rice terraces, the municipality of Banaue is abounds with a variety of natural resources catering to adventure ecotourism, one of which is the Tapiyah waterfalls. As described by the Provincial Planning Office of Ifugao (PPDO-Ifugao), the ecotourism sites considered in the study are:

1. Banaue rice terraces. It is located at Barangay Viewpoint, which is about 15 minutes' drive from the town center of Banaue. Several view decks are established to serve as viewing area while enjoying the scenic beauty of the terraces. The rice terraces rise steeply from the base of the mountain range to a height of a few thousand feet.

2. Batad rice terraces. The rice terraces of Batad are tiered and take the shape of an amphitheater. Batad, can be reached through a concreated road from the town proper until a hill called "Saddle". From the hill, it takes about twenty (20) minutes downhill hike through a trail to reach the famous terraces. 


\section{International Journal of Science and Research (IJSR) \\ ISSN (Online): 2319-7064}

Index Copernicus Value (2013): 6.14 | Impact Factor (2015): 6.391

3. Tappiyah waterfalls. It is a spectacular waterfall with a phenomenal 70-meter fall that drops to a large natural swimming pool. The waterfalls are situated at Barangay Batad, Banaue Ifugao. It is adjacent to the Batad rice terraces. Tourists usually enjoy the crystal clear water of the falls after trekking the Batad rice terraces.

4. Bangaan rice terraces. Surrounded by scenic terraced rice fields is a picturesque village whose inhabitants continue to preserve their traditional way of life. The rice terrace is characterized by having a pot-shaped formation when viewed from the center of the barangay.

\section{Research Methodology}

The study used descriptive research method to acquire data. A survey questionnaires were administered to 104 international and domestic tourists who visited the ecotourism sites of Banaue, Ifugao such as Banaue rice terraces, Batad rice terraces, Bangaan rice terraces and Tapiya waterfalls from May to June 2015. A series of interviews were conducted to augment the gathered data through the questionnaire. The questionnaire was pre-tested to domestic tourists and was revised based from feedback received.

Data generated were analyzed using simple descriptive statistics like percentage and frequency, correlation of variables and analysis of variance using the Statistical Packaged for Social Sciences (SPSS) and presented in the form of table.

\section{Results and Discussions}

\subsection{Demographic Profile of the Ecotourists}

The demographic profile of the respondents considered in the study includes gender, age, marital status, types of tourist and educational levels. Table 1 shows the frequency and percent distribution of the demographic profile of the tourists. It shows that there were more than one half $(55.80 \%)$ of the tourist respondents were females while $44.20 \%$ were male who visited the ecotourism sites. Comparing the four tourism sites, more female visited Viewpoint rice terraces (40) followed by Batad rice terraces (8), Tapiya falls (7) and Bangaan Rice Terraces (3). The result could be accounted to the accessibility of the ecotourism sites.

The tourist respondents were on their active stage since the dominant age group of the tourists was 21 to 30 years old with $41.35 \%$ of the respondents, 20 years old and below made up the smallest group, representing $8.65 \%$ and the mean age was 31 years old.

Most of the tourists were single accounting to $59.6 \%$ of the total population. Accordingly, singles have lesser family responsibility; they have time to visit other places to unwind as stated by the respondents during the interview. In the other hand, there were $42(40.40 \%)$ domestic/balikbayan tourists. It is already a common practice in the country that balikbayans together with their families and/or friends are visiting tourist destinations to relax from tedious work.
Forty-six of the tourist respondents finished graduate school/or with units earned dominates and the least were 8 respondents who were secondary graduates. The result of the level of education indicates that most of the tourists who visited the sites have relatively high educational attainment.

Table 1: Frequency and percent distribution of the demographic profile of the tourists

\begin{tabular}{|c|c|c|}
\hline Information sought & Frequency & Percentage \\
\hline Gender & & \\
\hline Male & 46 & 44.20 \\
\hline Female & 58 & 55.80 \\
\hline Age (years) & & \\
\hline 20 yrs. old \& below & 9 & 8.65 \\
\hline $21-30$ yrs old & 43 & 41.35 \\
\hline $31-40$ yrs old & 22 & 21.15 \\
\hline $41-50$ yrs old & 12 & 11.54 \\
\hline Above 50 yrs old & 18 & 17.31 \\
\hline Marital Status & & 59.60 \\
\hline Single & 59.6 & 40.40 \\
\hline Married & 42 & 40.40 \\
\hline Type of Tourists & & 59.60 \\
\hline Domestic & 42 & 44.2 \\
\hline International & 62 & 32.7 \\
\hline Educational Attainment & & 15.4 \\
\hline $\begin{array}{c}\text { Graduate School/or } \\
\text { with units earned }\end{array}$ & 46 & 7.8 \\
\hline College Graduate & 34 & \\
\hline $\begin{array}{c}\text { Vocational/Technical } \\
\text { Courses/or } \\
\text { undergraduate }\end{array}$ & 16 & \\
\hline $\begin{array}{c}\text { Secondary Graduate } \\
\text { (6) }\end{array}$ & 8 & \\
\hline
\end{tabular}

\subsection{Travel Behavior Characteristics}

Table 2 presents the frequency distribution of the travel behavior characteristics of the respondents. Majority (73.1\%) mentioned that it was their first visit to the ecotourism sites and there were 76 tourist's respondents who did not have any previous experience with the sites. Nevertheless, 18 tourists visited 2 to 4 times and the least was 3 tourists who mentioned that they visited the ecotourism sites 3 times.

As to the length of stay, 70 tourists stayed for 1 to 3 days, a minimal number (5) of tourists stayed more than 9 days. The average length of stay was 4.23 days which is higher than the report from the PPDO of Ifugao that the average length of stay of tourists in province is 2.5 days. In the category plan of travel, majority $(67.30 \%)$ of the respondents planned in advance their trip for less than three months and the least was 3-6 months having 8 respondents.

The study further disclosed that 30 of the tourists preferred to travel with friends followed by 29 each traveled with their families and relatives, and organized groups. These tourists found the sites an avenue where they can enjoy accompanied with their friends, families and relatives. The tourists in groups were found in Viewpoint rice terraces and Bangaan rice terraces due to accessibility as mentioned by them. There were at least 16 tourist respondents who visited the sites alone, although they admitted that they prefer to visit the sites in groups if they will be given another chance. Most of the tourist respondents knew the sites from the internet (52),

\section{Volume 5 Issue 6, June 2016 www.ijsr.net}




\section{International Journal of Science and Research (IJSR) \\ ISSN (Online): 2319-7064}

Index Copernicus Value (2013): 6.14 | Impact Factor (2015): 6.391

friends and family (41), Tourist brochure/guidebooks (40) and the least information were 9 tourist respondents each knew from television/radio and previous visit.

Table 2: Frequency distribution of the travel behavior characteristics of the tourists

\begin{tabular}{|c|c|c|}
\hline Information Sought & Frequency & Percentage \\
\hline \multicolumn{3}{|l|}{$\begin{array}{l}\text { Is this your first visit to } \\
\text { Banaue Eco-tourism Sites? }\end{array}$} \\
\hline Yes & 76 & 73.1 \\
\hline No & 28 & 26.9 \\
\hline \multicolumn{3}{|l|}{ Length of stay } \\
\hline 1 to 3 days & 70 & 67.31 \\
\hline 4 to 6 days & 22 & 21.15 \\
\hline 7 to 9 days & 7 & 6.73 \\
\hline 10 days and above & 5 & 4.81 \\
\hline \multicolumn{3}{|l|}{$\begin{array}{l}\text { How long in advance did you } \\
\text { planned to visit Banaue? }\end{array}$} \\
\hline Less than 3 mons & 70 & 67.3 \\
\hline 3 to 6 mons & 11 & 10.6 \\
\hline Over 6 mons & 23 & 22.1 \\
\hline \multicolumn{3}{|l|}{ Describe your travel? } \\
\hline Alone & 16 & 15.40 \\
\hline Family and/or relatives & 29 & 27.90 \\
\hline Friends & 30 & 28.80 \\
\hline Organized groups & 29 & 27.80 \\
\hline \multicolumn{3}{|l|}{$\begin{array}{l}\text { What is/are Your Sources of } \\
\text { Information }\end{array}$} \\
\hline Family and/or friends & 41 & 39.42 \\
\hline Previous Visits & 6 & 5.77 \\
\hline Internet & 52 & 50.00 \\
\hline Travel Agency/ies & 13 & 12.50 \\
\hline TV/Radio & 6 & 5.77 \\
\hline Newspapers/Magazines & 9 & 8.65 \\
\hline Tourist brochure/guidebooks & 40 & 38.46 \\
\hline Word of mouth & 18 & 17.31 \\
\hline
\end{tabular}

*Multiple responses expressed in absolute numbers

4.3 Correlation of Tourist Satisfaction with some Variables of Demographic Profile, Travel Behavior and Expectation

The profile variables of ecotourism such as days spend and expectations were found to be significant when correlated with satisfaction of tourists. The other profile variables such as age and income were not significant to satisfaction. Usually when the tourists are satisfied with the ecotourism sites they visited, they tend to spend more days on the destination than what was initially planned by them. The ecotourism sites at Banaue were furnished with affordable lodging facilities and restaurants. Bangaan Rice terraces and Tapiya falls do not have an onsite lodging facilities and refreshments/restaurants but these are sufficed by the presence of land transportation facilities for Bangaan and the distance to available support facilities such as Inn/lodging and restaurants for Tapiya waterfall is short.
Table 3: Correlation of satisfaction with some variables of demographic profile, travel behavior and expectation

\begin{tabular}{|c|c|c|c|}
\hline Profile & $\begin{array}{c}\text { Correlation } \\
\text { Coefficient }\end{array}$ & $p$-value & Remarks \\
\hline Age & -0.153 & 0.122 & $\begin{array}{c}\text { No significant } \\
\text { Correlation }\end{array}$ \\
\hline Income & -0.127 & 0.258 & $\begin{array}{c}\text { No significant } \\
\text { Correlation }\end{array}$ \\
\hline Days spent & $.211^{*}$ & 0.031 & $\begin{array}{c}\text { Significant } \\
\text { Correlation }\end{array}$ \\
\hline Expectation & $.626^{* *}$ & 0.000 & $\begin{array}{c}\text { Significant } \\
\text { Correlation }\end{array}$ \\
\hline
\end{tabular}

\subsection{Correlation between the Levels of Expectation and Satisfaction of Tourists}

Table 4 shows the correlation between the levels of expectation and satisfaction of tourist in Banaue. The result revealed that there is a significant difference in the level of expectation and satisfaction of tourist with respect to tour attraction and maintenance factor variables. It is remarkable that the mean values of all the variables in terms of expectation are classified as moderate but the levels of satisfaction of the variables are all classified as much satisfied. Moderate expectations are best, as the possibility of moderately satisfied or highly satisfied tourist's increases, thereby ensuring returning clientele, which is the major motive of all destination [2b]. The finding reveals that most of the ecotourists respondents are not well informed or knowledgeable about the ecotourism sites at Banaue.

Akama and Kieti [4] stressed that expectations are formed through information from advertisements and word of mouth perceptions from other tourists during past experience. In the other hand, according to A.S. Lather, R. Singh \& K. A. Singh expectations would rely more on the influence of past experience than sources of information.

\subsection{Overall Tourist Satisfaction on Ecotourism Sites}

Table 5 presents the overall satisfaction of Tourist in all the ecotourism sites located at Banaue such as Banaue rice terraces, Batad rice terraces, Bangaan rice terraces and Tappiyah waterfalls. The tourists were much satisfied in all the ecotourism sites as reflected in the computed mean that range from 4.65-525 with an overall mean of 4.86. The result indicates that the tourists are satisfied on the different attractions of each of the ecotourism sites. Satisfied tourist is expected to revisit and stay longer in the ecotourism destination. 
International Journal of Science and Research (IJSR)

ISSN (Online): 2319-7064

Index Copernicus Value (2013): 6.14 | Impact Factor (2015): 6.391

\begin{tabular}{|c|c|c|c|c|c|c|c|}
\hline \multirow{2}{*}{$\begin{array}{c}\text { Attraction and } \\
\text { Maintenance Factor of } \\
\text { Ecotourism Sites }\end{array}$} & \multicolumn{2}{|c|}{ Expectation } & \multicolumn{2}{|c|}{ Satisfaction } & \multirow[b]{2}{*}{ t-value } & \multirow[b]{2}{*}{ p-value } & \multirow[b]{2}{*}{ Remarks } \\
\hline & Mean & Description & Mean & Description & & & \\
\hline Heritage Attraction & 4.20 & moderate & 4.78 & much & 1.924 & 0.103 & $\begin{array}{l}\text { No Significant } \\
\text { Difference }\end{array}$ \\
\hline Cultural Attraction & 4.40 & moderate & 4.69 & much & 1.590 & 0.150 & $\begin{array}{c}\text { No Significant } \\
\text { Difference }\end{array}$ \\
\hline General Tour Attraction & 4.04 & moderate & 4.34 & much & 2.952 & 0.011 & Significant Difference \\
\hline Maintenance Factor & 4.06 & moderate & 4.38 & much & 2.248 & 0.048 & Significant Difference \\
\hline
\end{tabular}

\begin{tabular}{|c|c|c|}
\hline Ecotourism Sites & Mean & Description \\
\hline Viewpoint rice terraces & 4.79 & Much satisfied \\
\hline Batad rice terraces & 5.25 & Much satisfied \\
\hline Bangaan rice terraces & 4.65 & Much satisfied \\
\hline Tappiyah waterfalls & 4.74 & Much satisfied \\
\hline Over-all & 4.86 & Much satisfied \\
\hline
\end{tabular}

\section{Conclusions and Recommendations}

As shown in the result of the study, the tourist who visited the ecotourism sites in Banaue expected moderately in terms of heritage attraction, cultural attraction, general tour attraction and maintenance factor. However, the tourists are much satisfied when they visited the ecotourism sites. Significant differences were found on general tour attraction and maintenance factor when expectation where correlated with satisfaction. The days spend and expectations of tourist were found to be significant when correlated with satisfaction. The tourist who visited all the ecotourism sites was much satisfied.

Provision of sufficient fund to maintain and improve the tourism sites and a more effective promotional and marketing strategy may be recommended to attract a countless number of tourists to visit, and stay longer at Banaue, Ifugao.

\section{References}

[1] National Economic and Development Authority. 2004 "Cordillera Administrative Region Regional Development Plan 2004-2010”. Baguio City, Philippines

[2] A.S. Lather, R. Singh \& K. A. Singh, "Comparing the Levels of Expectation and Satisfaction of Indian and Provincial Planning and Development Office Ifugao Province. "Provincial Development and Physical Framework Plan of Ifugao 2011-2016".

[3] Akama J.S. and Kieti, D.M. (2003). "Measuring Tourist Satisfaction with Kenya's Wildlife Safari: A Case Study of Tsavo West National Park," International Journal of Tourism Management, 24(1): pp 73-81.

\section{Author Profile}

Milton P. Dulay finished Bachelor of Science in Forestry, Master of Science in Forestry, Doctor of Philosophy in Resource Management, and a faculty of College of Agriculture and Forestry of Ifugao State University, Alfonso Lista, Ifugao.

Volume 5 Issue 6, June 2016 www.ijsr.net 